\title{
Dealing With Complexity and Extreme Events Using a Bottom-Up, Resource-Based Vulnerability Perspective
}

\author{
Roger A. Pielke Sr., ${ }^{1}$ Rob Wilby, ${ }^{2}$ Dev Niyogi, ${ }^{3}$ Faisal Hossain, ${ }^{4}$ Koji Dairuku, ${ }^{5}$ Jimmy Adegoke, ${ }^{6}$ \\ George Kallos, ${ }^{7}$ Timothy Seastedt, ${ }^{8}$ and Katharine Suding ${ }^{9}$
}

\begin{abstract}
We discuss the adoption of a bottom-up, resource-based vulnerability approach in evaluating the effect of climate and other environmental and societal threats to societally critical resources. This vulnerability concept requires the determination of the major threats to local and regional water, food, energy, human health, and ecosystem function resources from extreme events including those from climate but also from other social and environmental issues. After these threats are identified for each resource, then the relative risks can be compared with other risks in order to adopt optimal preferred mitigation/adaptation strategies. This is a more inclusive way of assessing risks, including from climate variability and climate change, than using the outcome vulnerability approach adopted by the Intergovernmental Panel on Climate Change (IPCC). A contextual vulnerability assessment using the bottom-up, resource-based framework is a more inclusive approach for policy makers to adopt effective mitigation and adaptation methodologies to deal with the complexity of the spectrum of social and environmental extreme events that will occur in the coming decades as the range of threats are assessed, beyond just the focus on $\mathrm{CO}_{2}$ and a few other greenhouse gases as emphasized in the IPCC assessments.
\end{abstract}

\section{INTRODUCTION}

Rial et al. [2004, p. 11] state the following:

The Earth's climate system is highly nonlinear: inputs and outputs are not proportional, change is often episodic and abrupt, rather than slow and gradual, and multiple equilibria are the norm . . . there is a relatively poor understanding of the different types of nonlinearities, how

\footnotetext{
${ }^{1}$ Cooperative Institute for Research in Environmental Sciences, University of Colorado, Boulder, Colorado, USA.

${ }^{2}$ Department of Geography, Loughborough University, Loughborough, UK.

${ }^{3}$ Department of Agronomy and Department of Earth and Atmospheric Sciences, Purdue University, West Lafayette, Indiana, USA.

Extreme Events and Natural Hazards: The Complexity Perspective Geophysical Monograph Series 196

(C) 2012. American Geophysical Union. All Rights Reserved.

10.1029/2011GM001086
}

they manifest under various conditions, and whether they reflect a climate system driven by astronomical forcings, by internal feedbacks, or by a combination of both ... [We] suggest a robust alternative to prediction that is based on using integrated assessments within the framework of vulnerability studies ... It is imperative that the Earth's climate system research community embraces this nonlinear paradigm if we are to move forward in the assessment of the human influence on climate.

\footnotetext{
${ }^{4}$ Department of Civil and Environmental Engineering, Tennessee Technological University, Cookeville, Tennessee, USA.

${ }^{5}$ Disaster Prevention System Research Center, National Research Institute for Earth Science and Disaster Prevention, Tsukuba, Japan.

${ }^{6}$ Natural Resources and the Environment, CSIR, Pretoria, South Africa.

${ }^{7}$ School of Physics, University of Athens, Athens, Greece.

${ }^{8}$ Institute of Arctic and Alpine Research, University of Colorado, Boulder, Colorado, USA.

${ }^{9}$ Department of Environmental Science, Policy, and Management, University of California, Berkeley, California, USA.
} 
The concept of spatiotemporal chaos (e.g., discussed by T. Milanovic (Spatio-temporal chaos, Climate Etc., Weblog, available at http://judithcurry.com/2011/02/10/spatio-temporalchaos, 2011)) reinforces this view of the complexity of the climate system and applies more generally to all components of society and the environment. Milanovic (paragraph 12) defines spatiotemporal chaos as dealing with the dynamics of spatial patterns:

Weather and climate are manifestations of spatio temporal chaos of staggering complexity because there is not only Navier Stokes equations, but there are many more coupled fields. ENSO is an example of a quasi standing wave of the system.

The dominant scientific perspective is top-down and carbon dioxide centric. It focuses on multidecadal global climate model (GCM) predictions involving quasilinear responses dominated by the increases in greenhouse gases, which are downscaled to societal and environmental impacts (i.e., following the progression from the Working Group 1 [Solomon et al., 2007] to the Working Group 2 reports [Parry et al., 2007], which culminate in the Working Group 3 report [Metz et al., 2007] of the Intergovernmental Panel on Climate Change
(IPCC)). This narrow approach, however, has serious limitations in assessing risks of extreme events to key resources as is discussed below. An overview of these limitations, presented in Figure 1, reproduced from the work of Kabat et al. [2004], includes the spatial averaging of climate predictions over relatively large areas, the focus on single stressors, and gradual, near-linear predictions of climate change.

An additional limitation of the top-down approach is that if the ensemble of IPCC projections and actual climate trajectory differ significantly in coming decades, recognition of this error may occur too late for policy makers to realign the adaptation/mitigation strategy in order to respond to the actual state of climate at the local/regional scale. In contrast, if the adaptation strategy had considered more scenarios, then it could handle a larger margin of error than the constrained top-down approach.

This chapter begins by overviewing the limitations of the top-down approach to assess risk from extreme events as well as the difficulty in detecting changes in the threat of extreme events over time. We then discuss a bottom-up resourcebased approach, which we conclude is a more robust tool to provide policy makers and the impact community with a

\begin{tabular}{|c|c|c|}
\hline Approach & Scenario & Vulnerability \\
\hline Assumed dominant stress & $\begin{array}{l}\text { Climate, recent greenhouse gas } \\
\text { emissions to the atmosphere, ocean } \\
\text { temperatures, aerosols, etc. }\end{array}$ & $\begin{array}{l}\text { Multiple Stresses: Climate } \\
\text { (historical climate variability, land } \\
\text { use and water use, altered } \\
\text { disturbance regimes invasive } \\
\text { species, contaminants/pollutants, } \\
\text { habitat loss, etc. }\end{array}$ \\
\hline Usual timeframe of concern & $\begin{array}{l}\text { Long-term, doubled } \mathrm{CO}_{2} 30 \text { to } 100 \\
\text { years in the future. }\end{array}$ & $\begin{array}{l}\text { Short-term (0-30 years) and long- } \\
\text { term research. }\end{array}$ \\
\hline Usual scale of concern & $\begin{array}{l}\text { Global,sometimes regional. Local } \\
\text { scale needs downscaling techniques. } \\
\text { However, there is little evidence to } \\
\text { suggest that present models provide } \\
\text { realistic, accurate, or precise climate } \\
\text { scenarios at local or regional scales. }\end{array}$ & $\begin{array}{l}\text { Local, regional, national, and global } \\
\text { scales. }\end{array}$ \\
\hline Major parameters of concern & $\begin{array}{l}\text { Spatially averaged changes in mean } \\
\text { temperatures and precipitation in } \\
\text { fairly large grid cells with some } \\
\text { regional scenarios for drought. }\end{array}$ & $\begin{array}{l}\text { Potential extreme values in multiple } \\
\text { parameters (temperature, } \\
\text { precipitations, frost-free days) and } \\
\text { additional focus on extreme events } \\
\text { (floods, fires, droughts, etc.) } \\
\text { measures of uncertainty. }\end{array}$ \\
\hline $\begin{array}{l}\text { Major limitations for developing } \\
\text { coping strategies }\end{array}$ & $\begin{array}{l}\text { Focus on single stress limits } \\
\text { preparedness for other stresses. } \\
\text { Results often show gradual ramping } \\
\text { of climate change-limiting } \\
\text { preparedness for extreme events. } \\
\text { Results represent only a limited } \\
\text { subset of all likely future outcomes - } \\
\text { usually unidirectional trends. } \\
\text { Results are accepted by many } \\
\text { scientists, the media, and the public } \\
\text { as actual "predictions". } \\
\text { Lost in the translation of results is } \\
\text { that all models of the distant future } \\
\text { have unstated (presently } \\
\text { unknowable) levels of certainty or } \\
\text { probability. }\end{array}$ & $\begin{array}{l}\text { Approach requires detailed data on } \\
\text { multiple stresses and their } \\
\text { interactions at local, regional, } \\
\text { national, and global scales - and } \\
\text { many areas lack adequate } \\
\text { information. } \\
\text { Emphasis on short-term issues may } \\
\text { limit preparedness for abrupt } \\
\text { "threshold" changes in climate } \\
\text { sometime in the short or long term. } \\
\text { Requires preparedness for a far } \\
\text { greater variation of possible futures, } \\
\text { including abrupt changes in any } \\
\text { direction - this is probably more } \\
\text { realistic, yet difficult. }\end{array}$ \\
\hline
\end{tabular}

Figure 1. Contrast between a top-down versus bottom-up assessment of the vulnerability of resources to climate variability and change. From the work of Kabat et al. [2004]. 
much better estimate of the threats faced by key resources in the future. We conclude the chapter with examples illustrating why we need a bottom-up approach to assess the threats to water, food, energy, human health, and ecosystem function.

\section{USE OF TOP-DOWN DOWNSCALING TO DETERMINE RISKS FROM EXTREME EVENTS}

IPCC climate change projections are at relatively coarser resolution [Solomon et al., 2007], whereas the impacts and potential mitigation policies of interest to stakeholders are mostly at local to regional scales. For example, climate models may project increasing drought at a regional scale. The resilience to such increased occurrence as well as changes in the intensity of droughts is, however, dependent on the local-scale environmental conditions (such as moisture storage and convective rainfall) and farming approaches (access to irrigation, timing of rain or stress, etc.). According to Adger [1996, p. 10] an important issue for IPCC-like global reports is to assess whether the top-down approach can incorporate the "aggregation of individual decisionmaking in a realistic way, so that results of the modelling are applicable and policy relevant."

There are also unresolved issues both for generating and applying IPCC-type model predictions to climate risk assessments for policy makers and other users [e.g., Holman et al., 2005]. They are often presented as "projections" yet are actually forecasts (predictions) of the future climate based on different assumptions of greenhouse gas emissions. Such terminology has been debated before by Pielke [2002] and MacCracken [2002]. In this chapter, we use the terms projection, prediction, and forecast interchangeably [Bray and von Storch, 2009].

Multidecadal IPCC-type forecasts, if used without consideration of regional and local vulnerabilities, can lead to misleading outcomes and actions for the impacts and adaptation community as well as for policy makers [Patt et al., 2010; Pielke Jr. et al., 2007].

There are several reasons why top-down IPCC-type multidecadal global climate change model predictions are not able to accurately predict changes in the climate system over this time period. First, as a necessary condition for an accurate prediction, the multidecadal GCM simulations must include all first-order climate forcings and feedback. However, they do not [see, e.g., National Research Council (NRC), 2005; Pielke et al., 2009]. Natural climate forcings, such as large volcanic eruptions or long-term changes in solar irradiance, cannot be forecast skillfully. Omission of these natural forcings, as well as human climate forcings that are excluded or poorly understood, introduces large uncertainty in the local and regional estimates of impact on the atmospheric and oceanic circulations [e.g., Myhre and Myhre, 2003; Matsui and Pielke, 2006; Davin et al., 2007].

Pielke et al. [2009, p. 413] state,

In addition to greenhouse gas emissions, other first-order human climate forcings are important to understanding the future behavior of Earth's climate. These forcings are spatially heterogeneous and include the effect of aerosols on clouds and associated precipitation [e.g., Rosenfeld et al., 2008], the influence of aerosol deposition (e.g., black carbon (soot) [Flanner et al., 2007] and reactive nitrogen [Galloway et $a l ., 2004]$ ), and the role of changes in land use/land cover [e.g., Takata et al., 2009]. Among their effects is their role in altering atmospheric and ocean circulation features away from what they would be in the natural climate system $[N R C, 2005]$. As with $\mathrm{CO}_{2}$, the lengths of time that they affect the climate are estimated to be on multidecadal time scales and longer.

Perhaps, at least partly for this reason, these global multidecadal predictions are unable to skillfully simulate major atmospheric circulation features such the Pacific Decadal Oscillation (PDO), the North Atlantic Oscillation (NAO), El Niño and La Niña, and the South Asian monsoon [Pielke Sr., 2010; Annamalai et al., 2007]. However, these large-scale atmospheric/ocean climate features determine the particular weather pattern for a region [e.g., Otterman et al., 2002; Chase et al., 2006]. Proposed decadal prediction efforts seek to address some of these deficiencies but are still under development [Hurrell et al., 2009].

Dynamic and statistical regional downscaling yield higher spatial resolution; however, the regional climate models are strongly dependent on the lateral boundary conditions and interior nudging by their parent global models [e.g., see Rockel et al., 2008]. Large-scale climate errors in the global models are retained and could even be amplified by the higher spatial-resolution regional models. Most downscaling methods also suffer from the inability to mimic second- or higher-order moments of climate variables on the regional and local scales and are typically conditioned to preserve the mean [Salathe, 2005]. In particular, the spatial gradient of precipitation may not be physically modeled well enough by downscaling methods to allow the accurate assessment of streamflow and other environmental features in regions of complex terrain [Ferraris et al., 2003; Salathe, 2005; Rahman et al., 2009; Yang et al., 2009].

Moreover, since as reported above, the global multidecadal climate model predictions cannot accurately predict circulation features such as PDO, NAO, El Niño, and La Niña [Compo et al., 2011], they cannot provide accurate lateral boundary conditions and interior nudging to the regional climate models. On the other hand, regional models themselves do not have the domain scale (or two-way interaction) to skillfully predict these larger-scale atmospheric features.

There is also only one-way interaction between regional and global models, which is not physically consistent. If the 
regional model significantly alters the atmospheric and/or ocean circulations, there is no way for this information to alter the larger-scale circulation features, which are being fed into the regional model through the lateral boundary conditions and nudging. Also, while there is information added when higher spatial analyses of land use and other forcings are considered in the regional domain, the errors and uncertainty from the larger model still persists, thus rendering the added complexity and details ineffective [Ray et al., 2010; Mishra et al., 2010].

In addition, lateral boundary conditions for input to regional downscaling require regional-scale information from a global forecast model. However, the global model does not have this regional-scale information because of its limited spatial resolution. This is, however, a logical paradox since the regional model needs something that can only be acquired by a regional model (or regional observations). Therefore, the acquisition of lateral boundary conditions with the needed spatial resolution becomes logically impossible.

There is sometimes an incorrect assumption that although GCMs cannot predict future climate change as an initial value problem, they can predict future climate statistics as a boundary value problem [Palmer et al., 2008]. With respect to weather patterns, for the downscaling regional (and global) models to add value over and beyond what is available from the historical, recent paleorecord, and worse-case sequence of days, however, they must be able to skillfully predict the changes in the regional weather statistics. There is only value for predicting climate change if they could skillfully predict the changes in the statistics of the weather and other aspects of the climate system. There is no evidence, however, that the models can predict changes in these climate statistics even in hindcast. As highlighted by Dessai et al. [2009], the finer and time-space-based downscaled information can be "misconstrued as accurate," but the ability to get this finer-scale information does not necessarily translate into increased confidence in the downscaled scenario [Fowler and Wilby, 2010].

Statistical downscaling from the parent global model can be used as the benchmark (control) against which dynamic downscaling should improve [e.g., Wilby et al., 1998; Mearns et al., 1999]. If, however, the statistical relationship(s) between predictor(s) and predictants changes in the future, the method will not provide the actual real-world response. Under climate change, the statistical relationship between the climate and impacts would be expected to change [Milly et al., 2008]. The same premise of stationarity also applies to the parameterized schemes within regional climate models.

There has also been a move toward higher spatial resolution and more complex GCMs. However, this added detail does not assure more skillful predictions of impacts to key resources decades from now. As concluded by Landsea and Knaff [2000, p. 2117], with respect to El Niño predictions, an increase in model complexity can, in fact, compound the input errors and downgrade the model skill. They write

. the use of more complex, physically realistic dynamical models does not automatically provide more reliable forecasts. Increased complexity can increase by orders of magnitude the sources for error, which can cause degradation in skill.

Thus, neither dynamic downscaling nor statistical downscaling from multidecadal global model projections add proven value to spatial or temporal accuracy that can assist the impact community in ways beyond what is already available from historical records, paleorecords, or analog records [Rajagopalan et al., 2009; Parson et al., 2003]. The global and regional multidecadal climate change models are providing a level of confidence in forecast skill of the coming decades that is not warranted.

\section{DETECTION TIME OF EXTREME EVENTS}

Historically, changes in exposure and the value of capital at risk have been much more important drivers of economic losses from weather-related hazards than anthropogenic climate change [Bouwer, 2011; Pielke Jr., 2010]. Nonetheless, our ability to detect future changes in extreme events depends on several additional factors: the strength of the

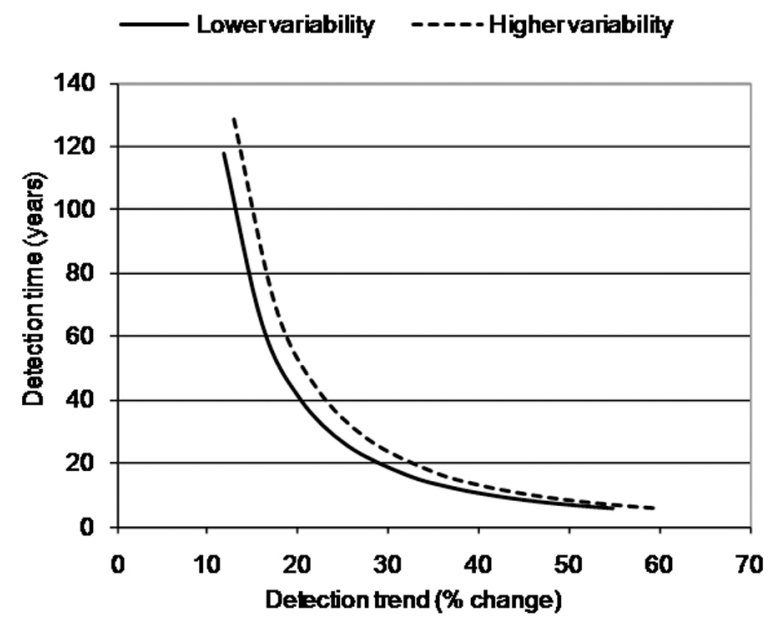

Figure 2. An example of the relationship between detection time (in years from 1990), the assumed strength of the climate change signal (percent change in mean), and interannual variability (variance) for summer flows in the River Itchen, southern England. This river had the shortest detection times (among the 15 basins studied) because of the relatively large climate changes projected for the region, combined with a large damping effect of groundwater on the flow regime. Adapted from the work of Wilby [2006]. 
predicted trend (signal) relative to the sample variance (noise), the length of time over which the trend persists, the choice of extreme index, the power of the statistical test, and the level of confidence required in the outcome of that statistical test (Figure 2). Quantitative predictions of extremes by climate models are highly uncertain due to the choice of model(s); unknown future changes in radiative and other climate forcing (by anthropogenic emissions, land surface modifications, and natural events (e.g., solar and volcanic)); and the random, internal variability of climate.

When taking all of these factors into account, it is hardly surprising that detection of robust anthropogenic signals in regional climate predictions is seldom possible within decision-making time scales of a few decades. For example, Ziegler et al. [2005] find that time series of 50-350 years are required to detect plausible trends in annual precipitation, evaporation, and discharge in the Missouri, Ohio, and Upper Mississippi River Basins. Likewise, Wilby [2006] showed that, under widely assumed climate change scenarios, expected trends in U.K. summer river flows are seldom detectable within typical planning horizons (i.e., by the 2020s). Again, depending on the climate model and underlying uncertainty of the regional projections, emergence time scales for U.S. tropical cyclone losses range between 120 and 550 years [Crompton et al., 2011].

Hawkins and Sutton [2010] consider the extent to which the signal-to-noise ratio in future temperature and precipitation might vary in space and time, as well as the scope for improving predictive power by decreasing climate model uncertainties. Using the Coupled Model Intercomparison Project (CMIP3) ensemble, they show that the tropics have the highest $\mathrm{S} / \mathrm{N}$ for temperature but the lowest for precipitation (which is greatest at the poles). Even when model uncertainty is set to zero, the gains in $\mathrm{S} / \mathrm{N}$ for regional precipitation are only modest, especially for predictions over the next few decades. However, other model experiments suggest that changes in indices of extreme precipitation may be stronger than corresponding changes in mean precipitation [Hegerl et al., 2004]. This view is supported by Fowler and Wilby [2010], who found that significant changes in multiday heavy rainfall accumulations could emerge in some parts of the United Kingdom within a decade or so (if the regional climate scenarios of the PRUDENCE ensemble are realized). Others assert that an attributable human fingerprint is already evident in the risk of flood occurrence at the scale of the United Kingdom [Pall et al., 2011].

So what is the utility of top-down climate model prediction and detection of extreme events? Taken at face value, poorly discerned and attributed changes in extreme events imply either that adaptation decisions will have to be taken ahead of tangible evidence of the need to act or that those anticipatory measures should simply be deferred. The latter argument is sometimes supported by naïve mismatching of trends in historic weather extremes with regional climate model projections [see Wilby et al., 2008].

Rather than an excuse for inaction, long emergence time scales reinforce the need for bottom-up, vulnerability-based responses. Anthropogenic climate change trends may already be underway but statistically undetectable for many more decades. This does not exclude the possibility that the same trends could have much earlier practical significance. For example, a rise in maximum temperatures of just a few tenths of a degree coinciding with lower river flows could result in abrupt changes in freshwater ecosystems that are already stressed by river regulation and pollution.

At least three steps can be taken to better detect complex, highly uncertain, and potentially dynamic patterns of extreme events. First, climate model outputs can be used to highlight potential "hot spots" of emerging risk (i.e., high $\mathrm{S} / \mathrm{N}$ ), thereby guiding a more targeted approach to environmental monitoring and assessment. For example, a strong signal is predicted for heavy rainfall in western England, particularly in the uplands. Early signs are that the expected trend may be emerging in the winter precipitation and streamflow record [Dixon et al., 2006; Fowler and Wilby, 2010]. Of course, there is always a danger of making type I errors in such cases (i.e., erroneous trend detection when there is none), but this risk diminishes as the trend remains and the record grows. We should, therefore, be safeguarding lengthy, homogeneous records, while being mindful of other factors that can confound trend analysis. These include changes in instrument, location, observing/ recording practice, site characteristics, and sampling regime [Pielke Sr. et al., 2007].

Second, regions with relatively low certainty in predicted extremes should be the focus for intensive field campaigns to improve understanding of regional climate forcing and representation in models. For example, large model uncertainty exists with respect to the future behavior of the South Asian monsoon. Rigorous scrutiny of the GCMs underpinning the IPCC reports revealed that just 6 of the 18 models have a plausible representation of monsoon precipitation climatology [Annamalai et al., 2007]. Of these six GCMs, only four exhibited a robust El Niño-Southern Oscillation (ENSO)monsoon correlation, including the well-known inverse relationship between ENSO and rainfall anomalies over India.

Another comprehensive assessment reviewed 79 GCM simulations from 12 different climate models and 6 different emission scenarios to ascertain whether any consensus can be reached about predicted changes in the main features of ENSO and the monsoon climates of South Asia [Paeth et al., 2008]. Although most models project La Nina-like 
anomalies, and thus an intensification of the summer monsoon precipitation in India by the end of the twenty-first century, the response is barely distinguishable from natural climate variability. Early detection is unlikely in this case.

Third, more judicious selection of indices could increase $\mathrm{S} / \mathrm{N}$, as in the case of long-duration precipitation extremes. We should also recognize that some types of extreme (such as droughts linked to persistent Atlantic blocking or intense summer convective downpours and associated flash flooding) are not adequately resolved by the present generation of climate models, even under present conditions [e.g., Fowler and Ekström, 2009] or is there any guarantee that higherresolution models will lead to reduced uncertainty, particularly if additional Earth system feedback are incorporated [Hawkins and Sutton, 2010]. However, by optimizing the choice of detection index, season and domain, it should be possible to identify a network of "sentinel" regions for earliest detection. But these hazard indices should not be so sophisticated that they lose societal relevance.

\section{A BOTTOM-UP, RESOURCE-BASED VULNERABILITY PERSPECTIVE}

\subsection{Definitions of Vulnerability}

In general, "vulnerability" may be defined as the concept of "threats" from potential hazards to the population, to key resources, and to the infrastructure. According to the IPCC Working Group 2 report [Parry et al., 2007, p. 21]

Vulnerability is the degree to which a system is susceptible to, and unable to cope with, adverse effects of climate change, including climate variability and extremes. Vulnerability is a function of the character, magnitude, and rate of climate change and variation to which a system is exposed, its sensitivity, and its adaptive capacity.

Bravo de Guenni et al. [2004] provides a useful summary below of the concept of vulnerability. Risk can be defined as a measure that combines, over a given time, the likelihoods and the consequences of a set of natural hazard scenarios [Beer and Ismail-Zadeh, 2003]. As summarized by A. Ismail-Zadeh (personal communication, 2011), the risk can be estimated as the probability of harmful consequences or expected losses (of lives and property) and damages (e.g., people injured, economic activity disrupted, environment damaged) due to a natural event resulting from interactions between hazards $(H s)$, vulnerability $(V)$, and exposure $(E)$. Conventionally, risk $(R s)$ is expressed quantitatively by the convolution of these three parameters: $R s=H s \times V \times E$. Such events can disrupt the human and/or the natural environment. A hazard is the combination of both the active physical exposure to a natural process and the vulnerability of the human and/or environmental system with which it is interacting. A hazard is commonly described as the "potential to do harm." The physical exposure is a function of both its intensity and duration. It has a magnitude and a probability of occurrence and takes place with respect to a particular resource at specified locations. The natural process becomes a hazard when it produces an event that exceeds a coping threshold, i.e., an extreme value. An extreme event, according to A. Ismail-Zadeh (personal communication, 2011), also could be more clearly defined as an occurrence that, with respect to other occurrences, is either notable, rare, unique, profound, or otherwise significant in terms of its impacts, effects, or outcomes. Hazard describes a phenomenon associated with a natural event (i.e., ground motion, ocean wave, atmospheric motion, etc.) that could cause harm and can be quantified by three parameters: a level of severity (expressed, for example, in terms of magnitude), and its occurrence frequency, and location. Hazard duration is determined by the length of time the threshold is exceeded. Resilience is the capacity of a system below which the thresholds of vulnerability are not exceeded [Vogel, 1998]. Figure 3 from the work of Bravo de Guenni et al. [2004] schematically illustrates the relationship between threshold and duration under different scenarios of threat and how they can change over time.

\subsection{Two Approaches to Assessing Vulnerability Approach}

The IPCC Fourth Assessment Report Working Groups (2 and 3) discuss vulnerability [Pielke and Niyogi, 2010; Schneider et al., 2007]. The IPCC identifies seven criteria for "key" vulnerabilities: magnitude of impacts, timing of

\section{A}

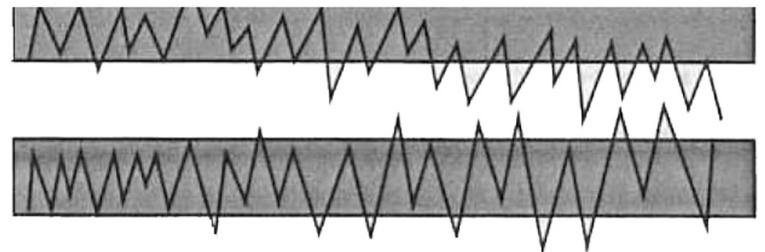

c
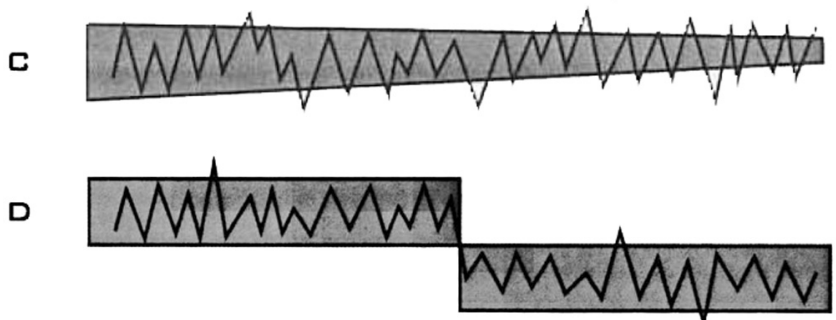

Figure 3. A schematic illustration in which risk changes because of variations in the physical system and the socioeconomic system. In all the cases, risk increases over time (with modifications after the work of Smith [1996]). From the work of Kabat et al. [2004]. 
impacts, persistence and reversibility of impacts, likelihood (estimates of uncertainty) of impacts and vulnerabilities and confidence in those estimates, potential for adaptation, distributional aspects of impacts and vulnerabilities, and the importance of the system(s) at risk.

The IPCC also refers to "outcome vulnerability" as illustrated in Figures 4 (left side) and 5 from the works of $O$ 'Brien et al. [2007] and Füssel [2007]. This is clearly a top-down driven perspective. The "contextual vulnerability" is, however, the more inclusive approach to assess risks to key resources since; rather than limiting to subset of threats, the entire spectrum of risks are considered.

For policy makers to develop resilient strategies, it is necessary to consider a multidimensional perspective as illustrated in Figure 6 (from the work of Hossain et al. [2011]) and Figure 4 (right side) (from the work of Füssel [2007]). Klein et al. [1999], for example, sought to determine whether the IPCC guidelines for assessing climate change impacts as well as adaptive strategies can be applied to the example of coastal adaptation. They recommend that a broader approach is needed, which has more local-scale information and input for assessing as well as monitoring the options. The missing link between local-scale features with global-scale projections becomes obvious.

The expanded eight-step approach of Schroter et al. [2005], designed to assess vulnerability to climate change, highlights the need to consider multiple interacting stresses.
They assume that climate change can be a result of greenhouse gas changes, which are coupled to socioeconomic developments, which, in turn, are coupled to land use changes and that all of these drivers are expected to interactively affect the human, environmental system (such as crop yields). Metzger et al. [2006] concluded that most existing assessment studies cannot provide needed information on regional vulnerability.

\section{EXAMPLES OF VULNERABILITY THRESHOLDS FOR KEY RESOURCES}

There are five broad areas that we can use to define the need for contextual vulnerability assessments: water, food, energy, human health, and ecosystem function. Each sector is critical societal well-being. The vulnerability concept requires the determination of the major threats to these resources from extreme events including climate but also from other social and environmental pressures. After these threats are identified for each resource, relative risks can be compared in order to shape the preferred mitigation/adaptation strategy.

The questions to be asked for each key resource are as follows:

1. Why is this resource important? How is it used? To what stakeholders is it valuable?

2. What are the key environmental and social variables that influence this resource?
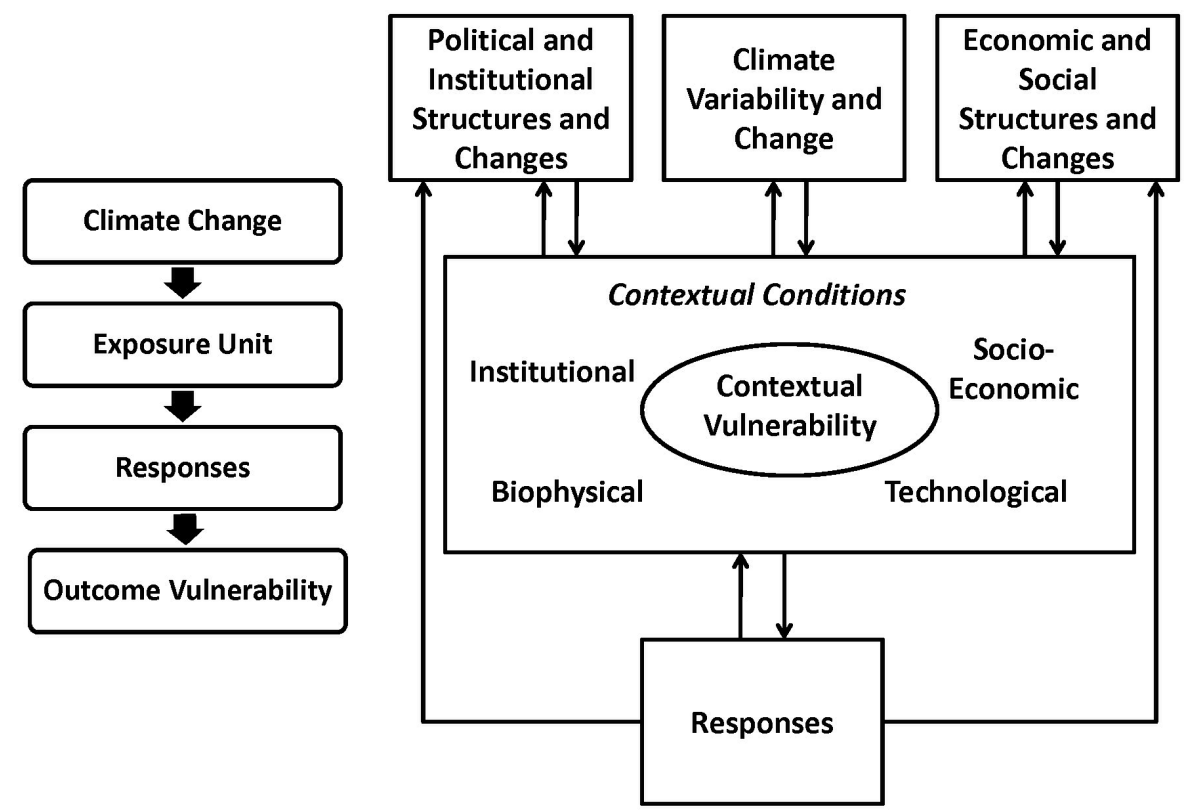

Figure 4. Framework depicting two interpretations of vulnerability to climate change: (left) outcome vulnerability and (right) contextual vulnerability. Adapted by D. Staley from the works of Füssel [2009] and O'Brien et al. [2007]. 


\begin{tabular}{|c|c|c|}
\hline & End-Point Interpretation & $\begin{array}{l}\text { Starting-Point } \\
\text { Interpretation }\end{array}$ \\
\hline Root problem & Climate change & Social vulnerability \\
\hline Policy context & $\begin{array}{l}\text { Climate change mitigation, } \\
\text { compensation, technical } \\
\text { adaptation }\end{array}$ & $\begin{array}{l}\text { Social adaptation, sustainable } \\
\text { development }\end{array}$ \\
\hline Illustrative policy question & $\begin{array}{l}\text { What are the benefits of } \\
\text { climate change mitigation? }\end{array}$ & $\begin{array}{l}\text { How can the vulnerability of } \\
\text { societies to climatic hazards } \\
\text { be reduced? }\end{array}$ \\
\hline Illustrative research question & $\begin{array}{l}\text { What are the expected net } \\
\text { impacts of climate change } \\
\text { in different regions? }\end{array}$ & $\begin{array}{l}\text { Why are some groups more } \\
\text { affected by climatic hazards } \\
\text { than others? }\end{array}$ \\
\hline $\begin{array}{l}\text { Vulnerability and adaptive } \\
\text { capacity }\end{array}$ & $\begin{array}{l}\text { Adaptive capacity determines } \\
\text { vulnerability }\end{array}$ & $\begin{array}{l}\text { Vulnerability determines } \\
\text { adaptive capacity }\end{array}$ \\
\hline $\begin{array}{l}\text { Reference for adaptive } \\
\text { capacity }\end{array}$ & $\begin{array}{l}\text { Adaptation to future climate } \\
\text { change }\end{array}$ & $\begin{array}{l}\text { Adaptation to current climate } \\
\text { variability }\end{array}$ \\
\hline Starting point of analysis & $\begin{array}{l}\text { Scenarios of future climate } \\
\text { hazards }\end{array}$ & $\begin{array}{l}\text { Current vulnerability to } \\
\text { climate stimuli }\end{array}$ \\
\hline Analytical function & Descriptive, positivist & Explanatory, normative \\
\hline Main discipline & Natural sciences & Social sciences \\
\hline Meaning of "vulnerability" & $\begin{array}{l}\text { Expected net damage for a } \\
\text { given level of global climate } \\
\text { change }\end{array}$ & $\begin{array}{l}\text { Susceptibility to climate } \\
\text { change and variability as } \\
\text { determined by socioeconomic } \\
\text { factors }\end{array}$ \\
\hline $\begin{array}{l}\text { Qualification according to the } \\
\text { terminology from Section } 2\end{array}$ & $\begin{array}{l}\text { Dynamic cross-scale } \\
\text { integrated vulnerability [of a } \\
\text { particular system] to a global } \\
\text { climate change }\end{array}$ & $\begin{array}{l}\text { Current internal } \\
\text { socioeconomic vulnerability } \\
\text { [of a particular social unit] to } \\
\text { all climatic stressors }\end{array}$ \\
\hline Vulnerability approach & Integrated, risk-hazard & Political economy \\
\hline Reference & McCarthy et al. [2001] & Adger [1999] \\
\hline
\end{tabular}

Figure 5. Two interpretations of vulnerability in climate change research. From the work of Füssel [2007, 2009].

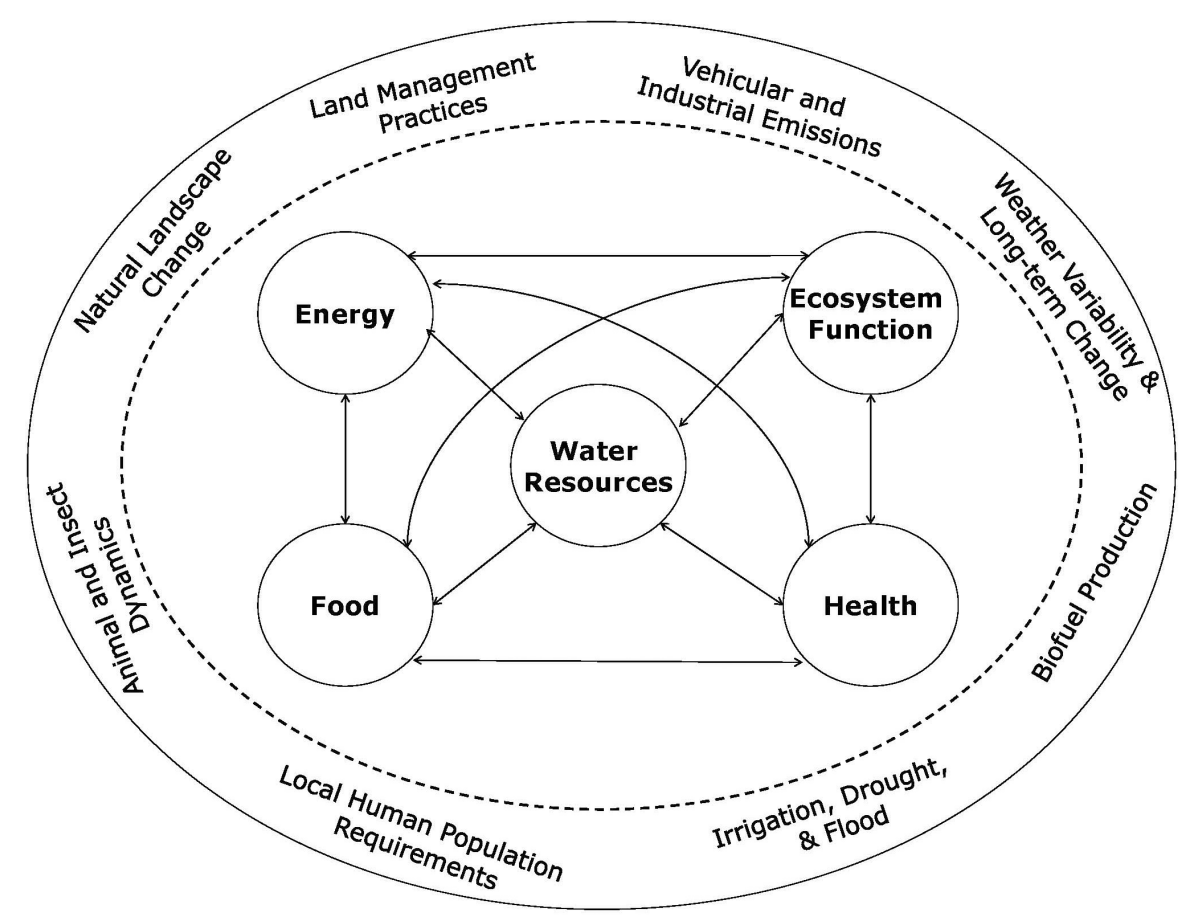

Figure 6. Schematic of the spectrum of risks to water resources. Other key resources associated with food, energy, human health, and ecosystem function can replace water resources in the central circle. From the work of Hossain et al. [2011]. 
3. What is the sensitivity of this resource to changes in each of these key variables? (This may include, but is not limited to, the sensitivity of the resource to climate variations and change on short (days), medium (seasons), and long (multidecadal) time scales.)

4. What changes (thresholds) in these key variables would have to occur to result in a negative (or positive) outcome for this resource?

5. What are the best estimates of the probabilities for these changes to occur? What tools are available to quantify the effect of these changes? Can these estimates be skillfully predicted?

6. What actions (adaptation/mitigation) can be undertaken in order to minimize or eliminate the negative consequences of these changes (or to optimize a positive response)?

7. What are specific recommendations for policy makers and other stakeholders?

Each of these concerns is explored in more detail in the following sections.

\subsection{Water}

To understand the vulnerability of water resources, we first need to recognize that the water that is usable can occur in various forms such as rainfall, surface water, rechargeable and fossil groundwater, snow, natural lakes, artificial reservoirs, and through state compacts and international treaties. The threats to these water resources are many, such as through health and contamination, changes in precipitation extremes, population demand, industrial and agricultural demand, contamination, national water policies, and climate [see Vörösmarty et al., 2010]. There may also be "competition" between different applications (resource production). For example, most of today's agriculture and fossil fuel-based energy production is water intensive [Jones, 2008]. Population and industrialization have continued to increase over the last century, which results in more competition for available water resources between direct consumption (for public and industrial water supply) and resource production (for crops and energy).

The resilience to known threats to water availability can be region specific and vary due to a multiplicity of factors. The factors affecting availability of water in most parts of the world are many, and at least more than a few key issues are involved [Vörösmarty et al., 2010]. The assessment of vulnerability of water resources requires an inherent recognition of these multiple threats (including from climate change and variability) to prioritize high-risk threats and plan adaptation strategies based on such multiple high-risk scenarios.

For example, let us consider for a country that the 50 year water availability is dictated overwhelmingly by rapid population growth and accompanying environmental degradation of water quality when compared to climate change (IPCC)based projections [e.g., see Vörösmarty et al., 2000]. A 50 year effective adaptation strategy that incorporates the 50 year population growth and expected water quality crises must therefore be resilient to any reasonably possible climate change. This is the inherent strength of a bottom-up approach versus the limited top-down counterpart.

\subsection{Food}

Agriculture, crop based as well as animal driven, is a riskprone entity. For example, assuming a global model projection for a future climate is accurate for a particular region, one could ascribe a range of climatic changes. These could include higher temperatures, greater propensity for more intense rainfalls, and higher $\mathrm{CO}_{2}$ levels. Each of these can positively affect the crop yield by promoting enhanced photosynthesis rates [Curtis et al., 2003; Jablonski et al., 2002] and taller and more robust crop and forest growth. Conversely, depending on the local conditions, the same changes could translate into increasing pest risk, higher ozone-related damages, increasing soil erosion risk, hail and frost damage, and reduced work days suitable for farm activities.

To extract the significance of the individual versus multiple climatic stressors on crop yields, Mera et al. [2006] developed a crop modeling study with over 25 different input scenarios of temperature, rainfall, and radiation changes at a farm scale for two crops that assimilate carbon differently (e.g., soybean and maize). As seen in many crop yield studies, the results suggested that yields were most sensitive to the amount of effective precipitation (estimated as rainfall minus physical evaporation/transpiration loss from the land surface). Changes in radiation had a nonlinear effect with crops showing an increased productivity for some reduction in the radiation as a result of cloudiness and increased diffuse radiation and a decline in yield with further reduction in radiation amounts. The impact of temperature changes, which has been at the heart of many climate projections, however, was quite limited, particularly if the soils did not have moisture stress. The analysis from the multiple climate change settings do not agree with those from individual changes, making a case for multivariable, ensemble approaches to identify the vulnerability and feedback when estimating climate-related impacts [cf. Turner et al., 2003].

A big unknown in food security, however, is the so-called nonclimatic risks. This could include agricultural policies such as those permitting genetic versus organic farming standards for the region as practiced in some European Union countries or the ethanol blending mandated in the Midwest United States. Even when considering the climatic factors alone, a large number of if-then probable scenarios 
can be developed that can have positive or negative impacts on crop yield and agricultural sustainability.

Niyogi and Mishra [2012] assess a number of stresses including a temperature increase, which can lead to increased yield for an initial period and can affect fertility, graining, and future generations and the timing of the temperature and rainfall, both of which would be a significant source of uncertainties. For example, reduced rainfall during the 2 week sowing period can translate into reduced yield even if the rainfall was adequate for the entire growing season. The stress on the plants, particularly from heavy rain and even frost during the young stage, would be much higher than during the mature period when the roots would be much deeper. The uncertainties also include pathogen and weed stress due to increased humidity and temperature interactions. Weeds are expected to be at significant advantage and not currently considered in conventional crop yield impact studies. From an adaptation perspective, if the farmers have information about possible droughts and sowed the seed deeper into the soil, which requires extra energy and time investment, the negative impacts could be alleviated.

Assessing the adaptation and mitigation approaches therefore requires a much broader view on the production processes and the life cycle of the entity than $\mathrm{CO}_{2}$-driven global model predictions can provide. Current crop impact studies adopt a typical approach in which the GCM scenario, often one or two extreme members instead of the ensemble, as input to simple process-based or statistical crop models. The bottom-up perspective provides a wider range of scenarios for the adaptive and mitigative strategies that individual growers, regional economies, and policy makers need to be able to respond to.

\subsection{Energy}

Two large categories of energy resources, namely, nuclear and renewable, are considered as unlimited, but this is practically untrue. The metals and other basic components used for producing the energy converters (e.g., nuclear reactors, solar cells, wind/wave generators, and farming of plants for biomass production) are limited and therefore vulnerable to human intervention. A more characteristic case is the growing need of materials with unique characteristics (rare metals). Climatic variability can influence all these energy resources in many ways. The increase of energy consumption requires intense mining of fossil fuels, increasing the areas covered by on/offshore renewable energy parks and platforms with a resultant substantial influence of local climate (e.g., due to changes in local wind and/or wave conditions from the physical presence of these structures).

Renewable energy is potentially vulnerable to climate variability and longer-term change. For example, biomass production involving land use change can alter the regional climate. Costa et al. [2007] found a significant reduction in rainfall when the land was converted to soybeans as contrasted with a conversion to grassland as a consequence of the larger albedo of the soybean fields. Wind turbines and solar panels are obviously strongly influenced by weather, and if they cover a large-enough area, it has been stated that they alter regional and even larger-scale climate patterns [see, e.g., Wang and Prinn, 2009]. Hydropower with its dependence on precipitation is obviously significantly affected by climate.

\subsection{Human Health}

The link between environmental conditions and human health is well established. Changes in weather and climate conditions on times scales ranging from days to decades can directly impact the conditions allowing certain diseases to flourish, on the one hand, while also affecting the exposure of human populations to disease, on the other.

For example, ranges and pathogen incubation periods of various vector-borne and waterborne diseases are directly linked to changes in climatic conditions (as is the case for malaria [see Githeko, 2009]). Similarly, heat-related morbidity and mortality associated with hot and cold waves are well documented [e.g., Keatinge et al., 2000]. Changes in the precipitation regimes, length of growing seasons, and increased dust from drought all contribute to respiratory allergies, asthma, and airway diseases in vulnerable populations. The challenge of addressing the effects of climate on human health is very complex because local or regional cultural, political, and economic factors can exacerbate environmental stressors, and the decisions that people make also influence health.

A host of factors such as biological susceptibility, socioeconomic status, cultural norms, and the quality of infrastructure often come into play in determining the vulnerability to climate-related disease conditions. Effective response strategies have to necessarily be region specific, and these must include defining environmental risk factors, identifying vulnerable populations, and developing effective risk communication and prevention strategies [Portier et al., 2010].

\subsection{Ecosystem Function}

Feedback from human activities have become directional drivers of change in both human and nonhuman-dominated ecosystems. These factors may be independent of climate change forcing, amplify, or attenuate the climate effects. For example, the fertilization of plants from enhanced atmospheric 
$\mathrm{CO}_{2}$, the positive and negative effects of nongreenhouse forms of inorganic nitrogen in the atmosphere, and the "wild card" effect of human-facilitated species introductions and extirpations are potentially changing local and regional landscapes as fast, or faster, than climate drivers [e.g., Vitousek et al., 1997; Hobbs et al., 2009]. Land use change can "trump" all of the above.

Thus, in considering how ecosystems will respond and interact in the twenty-first century, two points need to be emphasized. First, ecosystem function is vulnerable to human activities that are tangential to the climate drivers. Human activities have induced local and regional "tipping points" such as lake eutrophication [Carpenter and Lathrop, 2008] and desertification of rangelands [Schlesinger et al., 1990]. These events are occurring because of factors independent of climate forcings. Clear evidence of climate variations and longer-term change is also occurring in many areas; thus, scenario planning, mitigation, and adaptation require that we understand how these different facets of global environmental change interact with the climate system. How do these other anthropogenic activities alter outcomes? How will they influence the vulnerability of these systems to change?

The above questions lead to the second point. The response functions of ecosystems to the climate drivers are determined by the net effect of past drivers on the current structure of the ecosystem. Ecosystems can respond to climate forcings by exhibiting resilience, a phenomenon well exemplified by the relatively benign response of the Great Plains grasslands to the drought of the 1930s. Conversely, the same areas can experience transformation, i.e., the dust storms and destruction of millions of hectares of agricultural lands caused by the same 1930s drought. Clearly, climate alone was not the causal mechanism for the dust bowl, and we know now that the subsequent feedback to the regional climate from either a vegetated or barren landscape were substantial [e.g., Cook et al., 2009]. Resiliency and adaptive capacity is often associated with healthy diverse ecosystems; restoring ecosystem function of degraded ecosystems can convey resilience to future climate [McAlpine et al., 2010]. Thus, current decisions about land management will affect the ecosystem response functions that influence subsequent global climate change drivers.

\section{CONCLUSIONS}

The adoption of a vulnerability assessment approach to evaluate the effect of climate and other environmental and societal threats to key resources is an inclusive way of assessing risks, including from climate variability and longer-term climate change. In contrast to the outcome vulnerability adopted by the IPCC, the contextual vulnerability discussed by Füssel [2009] is more inclusive and provides a more robust framework for policy makers to adopt mitigation and adaptation methodologies to deal with the spectrum of social and environmental issues in the coming decades.

The concept of contextual vulnerability enables the determination of major threats to water, food, energy, human health, and ecosystem function from extreme events including those arising from climate but also other social and environmental pressures (as given by Pielke Jr. [2010], Wallace [2010], Webster and Hoyos [2010], J. Curry and P. Webster (Pakistan flood follow-up, Climate Etc., Weblog, available at http://judithcurry.com/2011/01/05/pakistanflood-follow-up/, 2010), and G. R. Carmichael (What goes around comes around: The globalization of air pollution and the implications for the quality of the air we breathe, the water we drink, and the food we eat, CIRES Distinguished Lecture Series, University of Colorado, Boulder, 6 March 2009)]. After these threats are identified for each resource, then relative risks can be determined in order to prioritize individual response measures and to shape the preferred mitigation/adaptation strategy.

Acknowledgments. The final editing of the paper was handled in the standard outstanding manner by Dallas Staley. Ray Taylor is thanked for alerting us to the Füssel article. Dev Niyogi acknowledges support from NSF CAREER ATM 0847472. Roger Pielke Sr. acknowledges support from NSF grant 0831331 . The authors thank Alik Ismail-Zadeh for his valuable suggested edits in the final version.

\section{REFERENCES}

Adger, W. N. (1996), Approaches to vulnerability to climate change, CSERGE Work. Pap. GEC 96-05, Cent. for Soc. and Econ. Res. on the Global Environ., Univ. of East Anglia, Norwich, U. K.

Adger, W. N. (1999), Social vulnerability to climate change and extremes in coastal Vietnam, World Dev., 27, 249-269.

Annamalai, H., K. Hamilton, and K. R. Sperber (2007), The South Asian summer monsoon and its relationship with ENSO in the IPCC AR4 simulations, J. Clim., 20, 1071-1092, doi:10.1175/ JCLI4035.1.

Beer, T., and A. T. Ismail-Zadeh (Eds.) (2003), Risk Science and Sustainability, 256 pp., Kluwer Acad., Dordrecht, Netherlands.

Bray, D., and H. von Storch (2009), 'Prediction' or 'Projection'? The nomenclature of climate science, Sci. Comm., 30, 534-543, doi:10.1177/1075547009333698.

Bouwer, L. M. (2011), Have disaster losses increased due to anthropogenic climate change?, Bull. Am. Meteorol. Soc., 92, 3946, doi:10.1175/2010BAMS3092.1.

Bravo de Guenni, L., R. E. Schulze, R. A. Pielke Sr., and M. F. Hutchinson (2004), The vulnerability approach, in Vegetation, Water, Humans and the Climate: A New Perspective on an 
Interactive System, edited by P. Kabat et al., chap. E.5, pp. 499514, Springer, New York.

Carpenter, S., and R. C. Lathrop (2008), Probabilistic estimate of a threshold for eutrophication, Ecosystems, 11, 601-613, doi:10. 1007/s10021-008-9145-0.

Chase, T. N., K. Wolter, R. A. Pielke Sr., and I. Rasool (2006), Was the 2003 European summer heat wave unusual in a global context?, Geophys. Res. Lett., 33, L23709, doi:10.1029/2006GL 027470 .

Compo, G. P., et al. (2011), The Twentieth Century Reanalysis Project, Q. J. R. Meteorol. Soc., 137, 1-28, doi:10.1002/qj.776.

Cook, B. I., R. L. Miller, and R. Seager (2009), Amplification of the North American Dust Bowl drought through human-induced land degradation, Proc. Natl. Acad. Sci. U. S. A., 106(13), 4997-5001, doi:10.1073/pnas.0810200106.

Costa, M. H., S. N. M. Yanagi, P. J. O. P. Souza, A. Ribeiro, and E. J. P. Rocha (2007), Climate change in Amazonia caused by soybean cropland expansion, as compared to caused by pastureland expansion, Geophys. Res. Lett., 34, L07706, doi:10.1029/ 2007GL029271.

Crompton, R. P., R. A. Pielke Jr., and K. J. McAneney (2011), Emergence timescales for detection of anthropogenic climate change in US tropical cyclone loss data, Environ. Res. Lett., 6, 014003, doi:10.1088/1748-9326/6/1/014003.

Curtis, P. S., L. M. Jablonski, and X. Wang (2003), Assessing elevated $\mathrm{CO}_{2}$ responses using meta-analysis, New Phytol., 160, 6-7, doi:10.1046/j.1469-8137.2003.00886.x.

Davin, E. L., N. de Noblet-Ducoudré, and P. Friedlingstein (2007), Impact of land cover change on surface climate: Relevance of the radiative forcing concept, Geophys. Res. Lett., 34, L13702, doi:10.1029/2007GL029678.

Dessai, S., M. Hulme, R. Lempert, and R. Pielke Jr. (2009), Do we need better predictions to adapt to a changing climate?, Eos Trans. AGU, 90(13), 111, doi:10.1029/2009EO130003.

Dixon, H., D. M. Lawler, and A. Y. Shamseldin (2006), Streamflow trends in western Britain, Geophys. Res. Lett., 33, L19406, doi:10.1029/2006GL027325.

Ferraris, L., S. Gabellani, N. Rebora, and A. Provenzale (2003), A comparison of stochastic models for spatial rainfall downscaling, Water Resour. Res., 39(12), 1368, doi:10.1029/2003WR002504.

Flanner, M. G., C. S. Zender, J. T. Randerson, and P. J. Rasch (2007), Present-day climate forcing and response from black carbon in snow, J. Geophys. Res., 112, D11202, doi:10.1029/ 2006JD008003.

Fowler, H. J., and M. Ekström (2009), Multi-model ensemble estimates of climate change impacts on UK seasonal rainfall extremes, Int. J. Climatol., 29, 385-416, doi:10.1002/joc.1827.

Fowler, H. J., and R. L. Wilby (2010), Detecting changes in seasonal precipitation extremes using regional climate model projections: Implications for managing fluvial flood risk, Water Resour. Res., 46, W03525, doi:10.1029/2008WR007636.

Füssel, H.-M. (2007), Vulnerability: A generally applicable conceptual framework for climate change research, Global Environ. Change, 17, 155-167.
Füssel, H.-M. (2009), Review and quantitative analysis of indices of climate change exposure, adaptive capacity, sensitivity, and impacts, background note, in World Development Report 2010: Development and Climate Change, report, 35 pp., World Bank, Washington, D. C. [Available at http://siteresources.worldbank. org/INTWDR2010/Resources/5287678-1255547194560/ WDR2010_BG_Note_Fussel.pdf.]

Galloway, J. N., et al. (2004), Nitrogen cycles: Past, present, and future, Biogeochemistry, 70(2), 153-226, doi:10.1007/s10533004-0370-0.

Githeko, A. K. (2009), Malaria and climate change, in Commonwealth Health Minister's Update 2009, pp. 40-43, Commonw. Secr., London, U. K. [Available online at http://www.thecom monwealth.org/files/190385/FileName/Githeko_2009.pdf.]

Hawkins, E., and R. Sutton (2010), The potential to narrow uncertainty in projections of regional precipitation change, Clim. Dyn., 37(12), 407-418, doi:10.1007/s00382-010-0810-6.

Hegerl, G. C., F. W. Zwiers, P. A. Stott, and V. V. Kharin (2004), Detectability of anthropogenic changes in temperature and precipitation extremes, J. Clim., 17, 3683-3700, doi:10.1175/15200442(2004)017<3683:DOACIA>2.0.CO;2.

Hobbs, R. J., E. Higgs, and J. A. Harris (2009), Novel ecosystems: Implications for conservation and restoration, Trends Ecol. Evol., 24, 599-605, doi:10.1016/j.tree.2009.05.012.

Holman, I. P., M. D. A. Rounsevell, S. Shackley, P. A. Harrison, R. J. Nicholls, P. M. Berry, and E. Audsley (2005), A regional, multi-sectoral and integrated assessment of the impacts of climate and socio-economic change in the UK, Part I. Methodology, Clim. Change, 71, 9-41, doi:10.1007/s10584-005-5927-y.

Hossain, F., D. Niyogi, J. Adegoke, G. Kallos, and R. Pielke Sr. (2011), Making sense of the water resources that will be available for future use, Eos Trans. AGU, 92(17), 144, doi:10.1029/2011E O170005.

Hurrell, J., G. A. Meehl, D. Bader, T. L. Delworth, B. Kirtman, and B. Wielicki (2009), A unified modeling approach to climate system prediction, Bull. Am. Meteorol. Soc., 90, 1819-1832.

Jablonski, L. M., X. Wang, and P. S. Curtis (2002), Plant reproduction under elevated $\mathrm{CO}_{2}$ conditions: A meta-analysis of reports on 79 crop and wild species, New Phytol., 156, 9-26, doi:10. 1046/j.1469-8137.2002.00494.x.

Jones, W. D. (2008), How much water does it take to make electricity?, IEEE Spectrum, 23 April. [Available at http://spectrum. ieee.org/energy/environment/how-much-water-does-it-take-tomake-electricity.]

Kabat, P., et al. (Eds.) (2004), Vegetation, Water, Humans and the Climate: A New Perspective on an Interactive System, 566 pp., Springer, Berlin.

Keatinge, W. R., G. C. Donaldson, E. Cordioli, M. Martinelli, A. E. Kunst, J. P. Mackenbach, S. Nayha, and I. Vuori (2000), Heat related mortality in warm and cold regions of Europe: Observational study, Br. Med. J., 321, 670-673, doi:10.1136/bmj.321. 7262.670 .

Klein, R. J. T., R. J. Nicholls, and N. Mimura (1999), Coastal adaptation to climate change: Can the IPCC technical guidelines 
be applied?, Mitigat. Adapt. Strat. Global Change, 4, 239-252, doi:10.1023/A:1009681207419.

Landsea, C. W., and J. A. Knaff (2000), How much skill was there in forecasting the very strong 1997-98 El Niño?, Bull. Am. Meteorol. Soc., 81(9), 2107-2120, doi:10.1175/1520-0477 (2000)081<2107:HMSWTI>2.3.CO;2.

MacCracken, M. (2002), Do the uncertainty ranges in the IPCC and U.S. National Assessments account adequately for possibly overlooked climatic influences, Clim. Change, 52, 13-23.

Matsui, T., and R. A. Pielke Sr. (2006), Measurement-based estimation of the spatial gradient of aerosol radiative forcing, Geophys. Res. Lett., 33, L11813, doi:10.1029/2006GL025974.

McCarthy, J. J., et al. (Eds.) (2001), Climate Change 2001: Impacts, Adaptation, and Vulnerability: Contribution of Working Group II to the Third Assessment Report of the Intergovernmental Panel on Climate Change, 1042 pp., Cambridge Univ. Press, Cambridge, U. K.

McAlpine, C. A., W. F. Laurance, J. G. Ryan, L. Seabrook, J. I. Syktus, A. E. Etter, P. M. Fearnside, P. Dargusch, and R. A. Pielke Sr. (2010), More than $\mathrm{CO}_{2}$ : A broader picture for managing climate change and variability to avoid ecosystem collapse, Curr. Opin. Environ. Sustainability, 2, 334-336, doi:10.1016/ j.cosust.2010.10.001.

Mearns, L. O., I. Bogardi, F. Giorgi, I. Matyasovszky, and M. Palecki (1999), Comparison of climate change scenarios generated from regional climate model experiments and statistical downscaling, J. Geophys. Res., 104(D6), 6603-6621, doi:10. 1029/1998JD200042.

Mera, R. J., D. Niyogi, G. S. Buol, G. G. Wilkerson, and F. Semazzi (2006), Potential individual versus simultaneous climate change effects on soybean $\left(\mathrm{C}_{3}\right)$ and maize $\left(\mathrm{C}_{4}\right)$ crops: An agrotechnology model based study, Global Planet. Change, 54, 163-182, doi:10. 1016/j.gloplacha.2005.11.003.

Metz, B., et al. (Eds.) (2007), Climate Change 2007: Mitigation of Climate Change: Contribution of Working Group III to the Fourth Assessment Report of the Intergovernmental Panel on Climate Change, 890 pp., Cambridge Univ. Press, Cambridge, U. K.

Metzger, M. J., M. D. A. Rounsevell, L. Acosta-Michlik, R. Leemans, and D. Schroter (2006), The vulnerability of ecosystem services to land use change, Agric. Ecosyst. Environ., 114, 69-85, doi:10.1016/j.agee.2005.11.025.

Milly, P. C. D., J. Betancourt, M. Falkenmark, R. M. Hirsch, Z. W. Kundzewicz, D. P. Lettenmaier, and R. J. Stouffer (2008), Stationarity is dead: Whither water management?, Science, 319 (5863), 573-574, doi:10.1126/science.1151915.

Mishra, V., K. A. Cherkauer, D. Niyogi, M. Lei, B. C. Pijanowski, D. K. Ray, L. C. Bowling, and G. Yang (2010), A regional scale assessment of land use/land cover and climatic changes on water and energy cycle in the upper Midwest United States, Int. J. Climatol., 30, 2025-2044, doi:10.1002/joc.2095.

Myhre, G., and A. Myhre (2003), Uncertainties in radiative forcing due to surface albedo changes caused by land-use changes, J. Clim., 16, 1511-1524.
National Research Council (NRC) (2005), Radiative Forcing of Climate Change: Expanding the Concept and Addressing Uncertainties, 208 pp., Natl. Acad. Press, Washington, D. C.

Niyogi, D., and V. Mishra (2012), Climate-agriculture vulnerability assessment for the midwestern United States, in Climate Change in the Midwest: Impacts, Risks, Vulnerability and Adaptation, edited by S. C. Pryor, Indiana Univ. Press, Bloomington, in press.

O'Brien, K. L., S. Eriksen, L. Nygaard, and A. Schjolden (2007), Why different interpretations of vulnerability matter in climate change discourses, Clim. Policy, 7(1), 73-88.

Otterman, J., et al. (2002), Are stronger North-Atlantic southwesterlies the forcing to the late winter warming in Europe?, Int. J. Climatol., 22, 743-750, doi:10.1002/joc.681.

Paeth, H., A. Scholten, P. Friederichs, and A. Hense (2008), Uncertainties in climate change prediction: El Niño-Southern Oscillation and monsoons, Global Planet. Change, 60, 265-288, doi:10.1016/j.gloplacha.2007.03.002.

Pall, P., T. Aina, D. A. Stone, P. A. Stott, T. Nozawa, A. G. Hilberts, D. Lohmann, and M. R. Allen (2011), Anthropogenic greenhouse gas contribution to flood risk in England and Wales in autumn 2000, Nature, 470, 382-386, doi:10.1038/nature09762.

Palmer, T. N., F. J. Doblas-Reyes, A. Weisheimer, and M. J. Rodwell (2008), Toward seamless prediction: Calibration of climate change projections using seasonal forecasts, Bull. Am. Meteorol. Soc., 89, 459-470, doi:10.1175/BAMS-89-4-459.

Parry, M. L., et al. (Eds.) (2007), Climate Change 2007: Impacts, Adaptation and Vulnerability: Contribution of Working Group II to the Fourth Assessment Report of the Intergovernmental Panel on Climate Change, 1000 pp., Cambridge Univ. Press, Cambridge, U. K.

Parson, E. A., et al. (2003), Understanding climatic impacts, vulnerabilities, and adaptation in the United States: Building a capacity for assessment, Clim. Change, 57, 9-42, doi:10.1023/ A:1022188519982.

Patt, A. G., D. P. van Vuuren, F. Berkhout, A. Aaheim, A. F. Hof, M. Isaac, and R. Mechler (2010), Adaptation in integrated assessment modeling: Where do we stand?, Clim. Change, 99, 383-402, doi:10.1007/s10584-009-9687-y.

Pielke, R. A., Jr. (2010), The Climate Fix: What Scientists and Politicians Won't Tell You About Global Warming, 288 pp., Basic Books, New York.

Pielke, R. A., Jr., G. Prins, S. Rayner, and D. Sarewitz (2007), Lifting the taboo on adaptation, Nature, 445(7128), 597-598, doi:10.1038/445597a.

Pielke, R. A., Sr. (2002), Overlooked issues in the U.S. National Climate and IPCC assessments, Clim. Change, 52, 1-11.

Pielke, R. A., Sr. (2010), Comment on "A unified modeling approach to climate system prediction”, Bull. Am. Meteorol. Soc., 91, 1699-1701, doi:10.1175/2010BAMS2975.1.

Pielke, R. A., Sr., and D. Niyogi (2010), The role of landscape processes within the climate system, in Landform-Structure, Evolution, Process Control, edited by J.-C. Otto and R. Didkau, Lect. Notes Earth Sci., 115, 67-85, doi:10.1007/978-3-54075761-0_5. 
Pielke, R. A., Sr., et al. (2007), Unresolved issues with the assessment of multidecadal global land surface temperature trends, J. Geophys. Res., 112, D24S08, doi:10.1029/2006JD008229.

Pielke, R. A., Sr., et al. (2009), Climate change: The need to consider human forcings besides greenhouse gases, Eos Trans. $A G U$, 90(45), 413, doi:10.1029/2009EO450008.

Portier, C. J., et al. (2010), A human health perspective on climate change: A report outlining the research needs on the human health effects of climate change, report, Environ. Health Perspect./Natl. Inst. of Environ. Health Sci., Research Triangle Part, N. C., doi:10.1289/ehp.1002272. [Available at www.niehs. nih.gov/climatereport.]

Rahman, S., A. C. Bagtzoglou, F. Hossain, L. Tang, L. Yarbrough, and G. Easson (2009), Investigating spatial downscaling of satellite rainfall data for flood prediction, J. Hydrometeorol., 10, 1063-1079, doi:10.1175/2009JHM1072.1.

Rajagopalan, B., K. Nowak, J. Prairie, M. Hoerling, B. Harding, J. Barsugli, A. Ray, and B. Udall (2009), Water supply risk on the Colorado River: Can management mitigate?, Water Resour. Res., 45, W08201, doi:10.1029/2008WR007652.

Ray, D. K., R. A. Pielke Sr., U. S. Nair, and D. Niyogi (2010), Roles of atmospheric and land surface data in dynamic regional downscaling, J. Geophys. Res., 115, D05102, doi:10.1029/2009JD 012218 .

Rial, J., et al. (2004), Nonlinearities, feedbacks and critical thresholds within the Earth's climate system, Clim. Change, $65,11-38$.

Rockel, B., C. L. Castro, R. A. Pielke Sr., H. von Storch, and G. Leoncini (2008), Dynamical downscaling: Assessment of model system dependent retained and added variability for two different regional climate models, J. Geophys. Res., 113, D21107, doi:10.1029/2007JD009461.

Rosenfeld, D., U. Lohmann, G. B. Raga, C. D. O’Dowd, M. Kulmala, S. Fuzzi, A. Reissell, and M. O. Andreae (2008), Flood or drought: How do aerosols affect precipitation?, Science, 321(5894), 1309-1313, doi:10.1126/science.1160606.

Salathe, E. P. (2005), Downscaling simulations of future global climate with application to hydrologic modelling, Int. J. Climatol., 25, 419-436, doi:10.1002/joc.1125.

Schlesinger, W. H., J. F. Reynolds, G. L. Cunningham, L. F. Huenneke, W. M. Jarrell, R. A. Virginia, and W. G. Whitford (1990), Biological feedbacks in global desertification, Science, 247, 1043-1048, doi:10.1126/science.247.4946.1043.

Schneider, S. H., et al. (2007), Assessing key vulnerabilities and the risk from climate change, in Climate Change 2007: Impacts, Adaptation and Vulnerability: Contribution of Working Group II to the Fourth Assessment Report of the Intergovernmental Panel on Climate Change, edited by M. L. Parry et al., pp. 779-810, Cambridge Univ. Press, Cambridge, U. K.

Schroeter, D., C. Polsky, and A. G. Patt (2005), Assessing vulnerabilities to the effects of global change: An eight step approach, Mitigat. Adapt. Strat. Global Change, 10, 573-595.

Smith, K. (1996), Environmental Hazards, 376 pp., Routledge, London, U. K.
Solomon, S., et al. (Eds.) (2007), Climate Change 2007: The Physical Science Basis: Contribution of Working Group I to the Fourth Assessment Report of the Intergovernmental Panel on Climate Change, 1056 pp., Cambridge Univ. Press, Cambridge, U. K.

Takata, K., K. Saito, and T. Yasunari (2009), Changes in the Asian monsoon climate during 1700-1850 induced by preindustrial cultivation, Proc. Natl. Acad. Sci. U. S. A., 106, 9586-9589, doi:10.1073/pnas.0807346106.

Turner, B. L., et al. (2003), A framework for vulnerability analysis in sustainability science, Proc. Natl. Acad. Sci. U. S. A., 100, 8074-8079, doi:10.1073/pnas.1231335100.

Vitousek, P., H. A. Mooney, J. Lubchenco, and J. M. Melillo (1997), Human domination of Earth's ecosystems, Science, 277, 494-499, doi:10.1126/science.277.5325.494.

Vogel, C. (1998), Vulnerability and global environmental change, LUCC Newsl., 3, 15-19.

Vörösmarty, C. J., P. Green, J. Salisbury, and R. B. Lammers (2000), Global water resources: Vulnerability from climate change and population growth, Science, 289, 284-288, doi:10. 1126/science.289.5477.284.

Vörösmarty, C. J., et al. (2010), Global threats to human water security and river biodiversity, Nature, 467, 555-561, doi:10. 1038/nature09440.

Wallace, J. M. (2010), Beyond climate change: Reframing the dialogue over environmental issues, Seattle Times, 26 March. [Available at http://seattletimes.nwsource.com/html/opinion/ 2011453141_guest28wallace.html.]

Wang, C., and R. G. Prinn (2009), Potential climatic impacts and reliability of very large-scale wind farm, Rep. 175, 21 pp., MIT Joint Program on the Sci. and Policy of Global Change, Cambridge, Mass. [Available at http://globalchange.mit.edu/files/ document/MITJPSPGC_Rpt175.pdf.]

Webster, P. J., and C. Hoyos (2004), Prediction of monsoon rainfall and river discharge on 15-30-day time scales, Bull. Am. Meteorol. Soc., 85, 1745-1767, doi:10.1175/BAMS-85-11-1745.

Wilby, R. L. (2006), When and where might climate change be detectable in UK river flows?, Geophys. Res. Lett., 33, L19407, doi:10.1029/2006GL027552.

Wilby, R. L., T. M. L. Wigley, D. Conway, P. D. Jones, B. C. Hewitson, J. Main, and D. S. Wilks (1998), Statistical downscaling of general circulation model output: A comparison of methods, Water Resour. Res., 34(11), 2995-3008, doi:10.1029/ 98WR02577.

Wilby, R. L., K. J. Beven, and N. S. Reynard (2008), Climate change and fluvial flood risk in the UK: More of the same?, Hydrol. Processes, 22, 2511-2523, doi:10.1002/hyp.6847.

Yang, G., L. C. Bowling, K. A. Cherkauer, B. C. Pijanowski, and D. Niyogi (2009), Hydroclimatic response of watersheds to urban intensity-An observational and modeling based analysis for the White River Basin, Indiana, J. Hydrometeorol., 11, 122-138, doi:10.1175/2009JHM1143.1.

Ziegler, A. D., E. P. Maurer, J. Sheffield, B. Nijssen, E. F. Wood, and D. P. Lettenmaier (2005), Detection time for plausible 
changes in annual precipitation, evapotranspiration, and streamflow in three Mississippi river sub-basins, Clim. Change, 72, 1736, doi:10.1007/s10584-005-5379-4.

J. Adegoke, Natural Resources and the Environment, CSIR, Pretoria 0001, South Africa. (jadegoke@csir.co.za)

K. Dairuku, Disaster Prevention System Research Center, National Research Institute for Earth Science and Disaster Prevention, 3-1 Tennodai, Tsukuba, Ibaraki 305-0006, Japan. (dairaku@bosai.go.jp)

F. Hossain, Department of Civil and Environmental Engineering, Tennessee Technological University, Cookeville, TN 385050001, USA. (FHossain@tntech.edu)

G. Kallos, School of Physics, University of Athens, 15784 Athens, Greece. (kallos@mg.uoa.gr)
D. Niyogi, Department of Earth and Atmospheric Sciences, Purdue University, West Lafayette, IN 47907, USA. (dniyogi@dniyogi@purdue.edu)

R. A. Pielke Sr., Cooperative Institute for Research in Environmental Sciences, University of Colorado, Boulder, CO 80309, USA. (pielkesr@cires.colorado.edu)

T. Seastedt, Institute of Arctic and Alpine Research, University of Colorado, Boulder, CO 80309, USA. (timothy.seastedt@colo rado.edu)

K. Suding, Department of Environmental Science, Policy, and Management, University of California at Berkeley, Berkeley, CA 94720-3114, USA. (suding@berkeley.edu)

R. Wilby, Department of Geography, Loughborough University, Loughborough LE11 3TU, UK. (R.L.Wilby@lboro.ac.uk) 
